\title{
Memory, identity and the archival paradigm: introduction to the special issue
}

\author{
Caroline Brown
}

Published online: 19 April 2013

(C) Springer Science+Business Media Dordrecht 2013

This number of Archival Science is a special issue featuring papers originally presented at the conference 'Memory, Identity and the Archival Paradigm: an interdisciplinary approach'. Held in Dundee at the end of 2010, the conference was hosted by the Centre for Archive and Information Studies at the University of Dundee and supported by the Royal Society of Edinburgh. The conference was part of a series of events organised by an interdisciplinary research network funded by the RSE and followed the successful Philosophy of the Archive conference, papers from which were published in Archival Science (9, 3-4, 2009). ${ }^{1}$ Archival literature frequently refers to the concepts of memory and identity but often without examining fully what these terms mean or the nature of their relationship to archives. The conference was an opportunity to encourage discussion and debate between people from a number of disciplines and the papers published in this issue each relate to some aspect of the role of archives and archivists in the creation and evolution of memory and identity. ${ }^{2}$ This introduction to this special issue reviews some of the current archival dialogue around memory and identity and provides an outline of how the articles in this issue complement or challenge this. ${ }^{3}$

Terry Cook, who opens this special issue with a reflection on the shifting and liberating nature of the archival role, has written frequently on the inter-relationship of archives, memory and identity. In an introduction to a previous special issue of Archival Science on Archives, Records and Power, Joan Schwartz and Terry Cook

\footnotetext{
1 More information about the Network and associated projects is at the Network website http://www.dundee.ac.uk/cais/memoryandidentity/research_network.htm and the introduction to the special edition (Whatley and Brown 2009).

2 Only some of the papers from the conference are published here. For a full list of speakers and abstracts of papers see http://www.dundee.ac.uk/cais/memoryandidentity/programme.htm.

3 For ease of reference the names of authors in this issue are printed in bold.
} 
argue that "Archives - as records-wield power over the shape and direction of historical scholarship, collective memory, and national identity, over how we know ourselves as individuals, groups, and societies' (Schwartz and Cook 2002, p. 2). Here, the notions of archives, history, memory, identity and power are interlinked, with archives taking a prominent role controlling and directing how we remember and how we, and others, see ourselves. Schwartz and Cook are concerned to shake complacent archivists free from their shackles of neutrality and impartiality and to introduce them to a world where archives control, privilege and marginalise and where archivists themselves, through such actions as appraisal, description and providing access, 'continually reshape, reinterpret and reinvent the archive'. By creating, changing and preserving the archive we form and reform history and through this and through the cultural frameworks and points of reference that archives create, we have power over memory and identity. They contend 'Memory, like history is rooted in archives. ... Archives are our memories' (Schwartz and Cook 2002, p. 18).

The connection between archives and heritage objects and memory and, more specifically, the impact of the actions of archivists and other curators on what is remembered and how it is remembered is explored by Susanne Belovari in her article in this issue 'Professional minutia and their consequences: provenance, context, original identification, and anthropology at the Field Museum of Natural History, Chicago, Illinois'. Using case studies from the museum world, she demonstrates that what is collected and how it is described and interpreted is dependent on the approach and attitude of curators and that this in turn impacts on how the history of people and objects is viewed and remembered. Rachel Bracha examines the use of archives by others to create, re-create and challenge memory with particular reference to artists and film. Whilst this use of archives in the creative arts may be problematic for some and may sit uncomfortably with notions of archives as evidence, for Bracha it has the (implicitly just) potential of challenging traditional memory. Referring to a film as an example, she argues, 'Before The Specialist, these archives were only used and replayed to cement a particular political moralizing remembrance strategy. Sivan's creative re-creation of archives threatened and disrupted the collective memory and identity of Israeli society. Arguably, it also "unblocked" a memory "drain" and enabled a new generation to reconsider their collective past, history and identity'.

This emphasis on justice and the power of archives is a familiar one in archival literature and one that is frequently linked to memory. We look to Derrida's description of the archive desire as one of 'forgetfulness, amnesia, the annihilation of memory' to remind us that the power of the archive is as much to do with forgetting as with remembering (Derrida 1995, p. 11). The contested realm in which we operate is one where certain stories are privileged and others marginalised by the decisions we take to keep, describe or open our collections. In seeking to be just, archivists must recognise that archives 'are witnesses not to unadorned truth but to invented contrivance. The word archive now conjures up confusion, conspiracy, exclusivity' (Lowenthal 2006, p. 51). To demonstrate the role of archives in remembering and forgetting, many authors point to the danger of archival power falling into the 'wrong hands' while seeking to equip archivists to be the 
'right hands' through a combination of self-awareness and contemplation of their moral and ethical responsibilities. Archival literature often concentrates on the destruction of records and the subsequent or potential loss of memory or eroding of identity but prejudice or persecution may equally be encouraged through the creation and keeping of records.

Comparisons between the creation and keeping of records and remembering, and between the destruction of records and forgetting, are not just confined to the recordkeeping profession. The spread of the Internet has encouraged writers to reflect on the dangers inherent in a world where individuals and society have constant access to information and where little if anything is deleted. They argue that as well as threatening our privacy and security, the permanence of digital information and records makes us more cautious and encourages us to stop taking risks (Mayer-Schönberger 2009). Moreover, the Internet changes not only what we remember or forget but how we remember. David Lowenthal's views are cautionary and frequently critical, 'Surfing the Web ... shortens attention spans, interrupts cognitive flow, mangles literary structure and privileges action over reflection' and, quoting a former Librarian of Congress, '[is] inherently destructive of memory' (Lowenthal 2006, p. 62). Writers of popular science, though more optimistic, often agree that 'thanks to search engines most simple facts don't need to be remembered' (Keim 2011).

Discussions about the relationship between media and memory are not new. As Margaret Hedstrom reminds us 'In the Phaedro, Plato contends that writing destroys memory because writing would allow memory skills to atrophy among those who became dependent on written memory aids' (Hedstrom 2002, p. 28). Students, as an introduction to the nature and purpose of archives, are often encouraged to consider the differences between oral and written societies and the impact of the latter on both evidence and memory; Clanchy's From memory to written record is likely to be on the syllabus at every archive school. Photographs and films are credited with forming more vivid and lasting memories but also, through manipulation, with creating false memories and forgetfulness, the eradication of figures such as Lenin and Trotsky from Soviet photographs is one example of this.

Discussions about archives and memory are not new, nor are contentions about the power of archives. However, several writers have cautioned that archivists writing about or referring to memory have not fully considered what they mean by the term or have oversimplified or generalised its relationship with archives (for example Brothman 2001; Hedstrom 2010). Concepts such as power and justice have received more considered treatment in literature, and there has been noticeably less concern amongst archivists about the equation of archives with memory than there has been amongst historians who seem more willing to deconstruct the ties between history and memory. However, archivists are drawing on these debates; for example, the distinction between history and memory is considered by Bastian who quotes some key writers such as Maurice Halbwachs 'In addition to written history, there is a living history that perpetuates and renews itself through time' and Pierre Nora to whom 'written history signals both the death of memory and of the unifying forces of nationhood that it signified' (Bastian 2009, pp. 117 and 118.) 
So what is the relationship between archives and memory? For Jenkins archives were a 'form of artificial memory', and several writers, Piggot and Hedstrom amongst them, have referred to archives as 'memory prosthesis'. This type of analogy suggests that the archive is both a less real or ghost-like manifestation of memory, and a type of crutch or support on which memory can rest and move forward. In the former, the archive is not memory itself but a reflection of it, the archive comes from and is dependent on memory. In the latter, memory itself is dependent on the archive to thrive.

Just as history is not the past, archives are not memory. Neither are archives storehouses of memory nor keepers of identity as neither memory nor identity are discrete objects which can be placed, hidden or revealed. For some, archives are memory carriers but perhaps memory prompters, triggers or building blocks is more apt, participating in the formation of memories along with other circumstances, individuals and objects (Hedstrom 2002; Piggot 2005; Flinn et al. 2009). 'Archival documents are not representatives of collective memory and archival institutions are no storehouses of collective memory. Rather archives are sources for the potential discovery or recovery of memories that have been lost' (Hedstrom 2010, p. 136). Or perhaps memories only exist in a fixed time and place, and cannot be lost or re-found, but are constantly created anew. As Brothman says 'Memory is not a place; it is a process ... Archivists need to see that records are cognitive artifacts as much as evidential artifacts' (Brothman 2001, p. 79). In this issue, Terry Cook in a wide-ranging article discusses history making and shaping and the apparent 'fractured schizophrenia' of the evidence-memory dichotomy. Cook believes we should reshape our archival mind-set, he traces the development of four shifting archival paradigms: evidence, memory, identity and community and believes that recognising that our role is constantly changing liberates us to embrace new directions. However, we cannot be changed or liberated without first understanding and examining our current position and place.

In an earlier issue of Archival Science, Verne Harris explored several of these themes contending that archives do not carry memory but participate in its creation and warning against what he saw as triumphalist notions that archives hold the collective memories of nations (Harris 2002). As many writers have argued, there are several participants in the creation of memory, some with as much, if not more, power than Harris' archival sliver. Attributing archives with notions of power and control over memory may have the danger of fetishising them; equating memory and archives is also problematic. Klein argues "The new "materialization" of memory thus grounds the elevation of memory to the status of a historical agent, and we enter a new age in which archives remember and statues forget' and he warns against explicit religiosity when discussing memory (Klein 2000, p. 136). Technological developments which allow for the easy creation and preservation of memory objects may perpetuate this. At a pop concert, a large part of the audience is likely to be preoccupied with filming or photographing the event rather than experiencing it directly themselves. This film will stand as a memory of an event that was not fully experienced first-hand. 'No epoch has deliberately produced so many archives as ours, due alike to technical advances in reproduction and conservation and to our superstitious respect for these traces. As traditional memory 
fades, we feel obliged religiously to accumulate the testimonies, documents, images and visible signs of what was' (Nora 1984, translated by Lowenthal 2006, p. 57).

The archive as prosthesis analogy sees memory being prompted by the archive but also conceives the archive as something created by memory. This symbiotic relationship which allows for records to both describe and create supports the notion that both memory and archives continually reinvent and recreate each other. Traditionally, the idea of memory itself becoming the record has been viewed as problematic. Just as historians did not view memory as embodied in oral testimonies as proper 'history', some archivists have not viewed oral recordings as a record to be preserved in an archive. However, traditional archives hold no claims to 'the truth' or to be a reflection of history and there is increasing support for archivists to be involved in the capturing of memory through non-traditional media. Oral recordings and interviews are being collected by archives as part of the record of the past. Organisations such as the Truth and Reconciliation Commissions are collecting oral testimony and accordingly legitimising memory and its place in the archive (Nannelli 2009). For Bastian, memory influences the production of records and she argues that 'archivists can make collective memory a tangible, transparent, and valuable component of their work, adding value to archival products'. Collective memory offers an alternative path to the past that complements and enhances archives, archivists must shift from traditional approaches and documentation towards 'documenting memory' (Bastian 2009, p. 116). For some writers, this might be achieved by encouraging community and individual participation and interaction with archival processes such as appraisal and cataloguing. For Jeannette Bastian, this can be done by capturing or recording non-written forms of commemoration, as she explains in her article in this issue of Archival Science 'The Records of Memory, the Archives of Identity: Celebrations, Texts and Archival Sensibilities'. Referring to cultural events, she argues that 'the general nature of these events—cyclical, commemorative, expressing, reflecting and representing vital aspects of the collective community identity-suggests that they function as records. That is, they operate within a context, they have a structure, and they contain and impart content'. Bastian examines how the traces and signifiers of cultures and traditions that are not generally recognised as archival can fit within an archival structure. The cultural archive that is created is inextricably linked to collective memory and communal identity and 'weaves seamlessly between past and present'.

Bastian writes about memories of societies, about collective rather than individual memory and throughout her writing a connection is made between this and identity. As with memory itself, archival literature tends to use rather than to define these terms although several authors quote Maurice Halbwachs, credited with first writing about collective memories and identities, who argued that memory is not simply 'the retrieval of stored information, but the putting together of a claim about past states of affairs by means of a framework of shared cultural understanding'. (Hedstrom 2010; Bastian 2009; Schwartz and Cook 2002, p. 3). This connection, common understanding and social coherence create shared and sustained memories which may be interpreted slightly differently by each individual in a group, but remain strong enough to be referred to as collective. The article by 
Trond Jacobsen, Ricardo L. Punzalan and Margaret Hedstrom seeks to compensate for the elusiveness and ambiguity of previous archival literature on memory. Their article 'Invoking "collective memory": Mapping the emergence of a concept in archival science' presents 'a systematic examination of the relationship between archives and collective memory as articulated in the archival literature'. The authors analyse citations to other works which appear in this literature and conclude that archivists should draw on research undertaken outside their own field while publicising their own work to other disciplines.

Interestingly, the digital world which has meant not just the proliferation of information but easier access to the past has divided writers over its impact on collective memory. For Lowenthal, the 'inflated archive' encouraged by new technology leads to 'navel-gazing' which 'crowds out the collective past' and, as we choose ourselves what to keep and remember, we lose the commonality of a shared past or cultural references (Lowenthal 2006, p. 71). This was a theme tackled in his paper for the Memory and Identity conference. As he contends in his abstract referring to ever growing Internet capacity, 'On the one hand it offers more comprehensive and egalitarian access to the past and enhanced historical insights. On the other hand it threatens a surfeit of diffuse personal trivia, Shandian infinite regress, and the loss of durable social frameworks grounded in cumulative, discriminating and dynamic collective memories' ${ }^{4}$ For others, however, the potentiality of the Internet to foster co-created, shared, linked and reusable data can only encourage the creation of communal experiences and thus a sense of collective or community, rather than individual, memory. Terry Cook calls on archivists to concentrate on this shared process rather than focussing on acquiring the archival products of processes. As he reflects in his article in this issue 'Some prominent archival voices are accordingly calling on archivists to give up their recently hardwon mantras of expert, of control, of power, and, instead, to share archiving with communities, both actual communities in our cities and countryside and virtual communities united by social media in cyberspace. There is simply too much evidence, too much memory, too much identity, to acquire more than a mere fragment of it in our established archives'.

For Klein, 'Memory is not a property of individual minds, but a diverse and shifting collection of material artifacts and social practises' (Klein 2000, p. 130). Collective memory is formed partly by the experiences created within these shifting frameworks, and this in turn contributes to the evolution of a sense of identity. Writing about the past Brothman argues that memory can sometimes feel like 'home' and that looking at the past might involve not only nostalgia and emotional longing but also a 'psychological and social processes of identity formation'. For Brothman, it is vital that archivists remember that 'Archives function as agents of political continuity and social solidarity, helping their respective societies to manage to hang together over time by serving as important self-affirming symbols of community identity and memory' (Brothman 2010, pp. 158-160).

\footnotetext{
${ }^{4}$ The abstract of David Lowenthal's paper 'Pandora's plenitude: archives for all forever?' is at http://www.dundee.ac.uk/cais/memoryandidentity/programme.htm.
} 
As Brothman argues, archives can promote cross-generational social coherence but they can also provoke social tensions and it is in this sense that the concept of identity has become politicised. The championing of identity privileges and empowers while it excludes and marginalises, and archives and archivists are implicit in this process. 'Archivists appraise, collect, and preserve the props with which notions of identity are built. In turn, notions of identity are confirmed and justified as historical documents validate with all their authority as "evidence" the identity stories so built' (Schwartz and Cook 2002, p. 16). In his paper on the development of the National Archives in South Africa reproduced in this issue, Graham Dominy reflects on the role of archives in the formation of collective memory and identities and on the absences, silences and distortions that can be found in (and in the interpretation and use of) the official record. Dominy's particular focus on the creation and archiving of the Freedom Charter serves as an example of the symbolic and political power of archives. The Charter itself not only fills some of the gaps in the official record but serves to legitimise the National Archives' role as a democratic institution. While Dominy acknowledges that this is problematic in that the archives become allied to a new dominant historical narrative, he argues that the acquisition of the Charter was pivotal to the National Archives' role in the post-Apartheid society.

Several writers have warned against taking a too simplistic approach to identity and viewing it as a definable state that can be enhanced by the creation and engagement of memory triggers and therefore by interaction with archives (Flinn et al. 2009). Archivists, fearful that their collections are unrepresentative and biased and wishing to contribute to the strengthening of identity of the underrepresented or minorities in their communities, direct their efforts to engaging users from these communities and seek to help preserve their memories and sense of identity by collecting and keeping their records. Kaplan sees these actions as evidence that archivists still harbour a belief in the archive as a repository of historical truth and a documenter of real identities and contends that this ignores recent 'serious' scholarship which refutes this reification of identity and its essentialist overtones. She quotes Lowenthal 'Heritage by its very nature excites partisan extremes... glamorizes narrow nationalism... [justifies] jingoism.... Heritage passions... play a vital role in national and ethnic conflict, in racism and resurgent genetic determinism' (Kaplan 2000, p. 147). Lowenthal argues that moves to protect the heritage of communities or groups by external bodies are fraught with contradiction-by seeking to identify and quantify these memory objects archivists and others are taking something away, 'National inventories of intangible cultural property (folklore, dance, ritual, music, craft skills) compiled under UNESCO aegis so as to protect native creativity by publicizing it, has only pushed tribal groups towards greater secrecy' (Lowenthal 2006, p. 65). In this issue, Daniel J. Caron and Andreas Kellerhals explore the role of memory institutions in the creation of identity, particularly through their approach to appraisal. In the light of the 'information deluge', they ask what the responsibilities of archivists are in regard to building and preserving the identities of groups concluding 'archives are not simple tools for nation building or for the construction of a given group's identity. They are not instruments for such purposes, but they may be instrumental in their effects'. 
Nevertheless, the marginalisation and absences in the archival record exist (Flinn et al. 2009). For many writers, the nature of archival endeavour is fraught with contradictions but the archivist's responsibility is to recognise these and to understand that an acknowledgement of complexities or of bias or politicisation is not a reason to retreat into protestations of impartiality. For Wallace, the realisation of the role that archives play in the construction of memory especially given the 'social identity promoted by archivists as guardians and trustworthy intergenerational transmitters of the past' demands further discussion and examination and an understanding of ethical responsibilities (Wallace 2011, p. 2). For Harris, these are clear: 'Far from being an impartial custodian, the archivist is a memory activist either for or against the oppression system. For deconstruction, to be human is to be an archivist, and there is no impartial custodian, period. Every act of custodianship is implicated in acts of constructing, representing, accessing and disseminating what is held in custody' (Harris 2011).

These themes are explored by Sonia Yaco and Beatriz Betancourt Hardy in their article in this issue 'Historians, archivists and social activism: benefits and costs'. Using the desegregation of Virginian education as an example, they discuss the role of historians and archivists as social activists intervening and preserving 'to ensure that the subject is not erased from our collective memories'. Their survey of the impact of activism on librarians, archivists, historians and their employers suggests that to play a political role does not come without a cost but they conclude that non-neutrality and intervention matter.

If archives, at least in part, trigger memories and help to create a sense of shared identities, it is an archivist's responsibility to recognise that memories will at the same time be forgotten and identities diluted, reduced or excluded by their actions. We should continue to try to give voice to the hidden whilst being mindful that the hidden might not want to be heard and that the forgotten may not wish us to create narratives for them.

\section{References}

Bastian JA (2009) Flowers for the Homestead: a case study in archives and collective memory. Am Arch 72:113-132

Brothman B (2001) The past that archives keep: memory, history, and the preservation of archival records. Archivaria 51:48-80

Brothman B (2010) Perfect present, perfect gift: finding a place for archival consciousness in social theory. Arch Sci 10:141-189

Derrida J (1995) Archive Fever. University of Chicago Press, Chicago and London

Flinn A, Stevens M, Shepherd E (2009) Whose memories, whose archives? Independent community archives, autonomy and the mainstream. Arch Sci 9:71-86

Harris V (2002) The archival sliver: power, memory, and archives in South Africa. Arch Sci 2:63-86

Harris V (2011) Jacques Derrida meets Nelson Mandela: archival ethics at the endgame. Arch Sci 11:113-124

Hedstrom M (2002) Archives, memory, and interfaces with the past. Arch Sci 2:21-43

Hedstrom M (2010) Archives and collective memory: more than a metaphor, less than an analogy. In: Eastwood T, MacNeil H (eds) Currents of archival thinking. Libraries Unlimited, Santa Barbara 
Kaplan E (2000) We are what we collect, we collect what we are: archives and the construction of identity. Am Arch 63:126-151

Keim B (2011) Search engines change how memory works. Wired http://www.wired.com/wiredscience/ 2011/07/search-engine-memory. Accessed July 2012

Klein KL (2000) On the emergence of memory in historical discourse. Representations 69:127-150

Lowenthal D (2006) Archival perils: an historian's plaint. Archives 114:49-75

Mayer-Schönberger V (2009) Delete: the virtue of forgetting in a digital Age. Princeton University Press, Princeton and Oxford

Nannelli E (2009) Memory, records, history: the Records of the Commission for Reception, Truth, and Reconciliation in Timor-Leste. Arch Sci 9:29-41

Piggot M (2005) Archives and Memory. In: McKemmish S et al (eds) Archives: recordkeeping in society. Charles Stuart University, Wagga-Wagga

Schwartz JM, Cook T (2002) Archives, records, and power: the making of modern memory. Arch Sci 2:1-19

Wallace DA (2011) Introduction: memory ethics—or the presence of the past in the present. Arch Sci $11: 1-12$

Whatley P, Brown C (eds) (2009) Special issue: The philosophy of the archive. Arch Sci 9:127-225

\section{Author Biography}

Caroline Brown is Programme Leader and Honorary Lecturer for the Archives and Records Management programmes at the Centre for Archive and Information Studies, University of Dundee. She is also Deputy Archivist at the University. Caroline has served on several national and international professional and academic bodies concerned with recordkeeping and education. Caroline's research interests include recordkeeping theory, appraisal, and the role of archives in creating individual and cultural memory and attributing value to archives. She was part of the project team which secured two Royal Society of Edinburgh grants (2007-2008 and 2009-2010) to promote interdisciplinary research into the archive with particular emphasis on the philosophy of the archive as it relates to memory and identity. She regularly writes and gives papers on recordkeeping theory and practice and approaches to archival education. 